\title{
THE SCIENCE OF CLIMATE CHANGE HOW TO TALK WITH SOCIETY?
}

\author{
International Conference \\ (Warsaw, Poland, 24th October 2013)
}

The conference on "THE SCIENCE OF CLIMATE CHANGE - HOW TO TALK WITH SOCIETY?" took place in Warsaw, Poland, on 24th October 2013. The co-organizers were: the Polish Academy of Sciences, the Institute for Sustainable Development (Warsaw), the Heinrich Böll Foundation, and the Polish Climate Coalition (Warsaw). The Conference was very well attended, with all 220 seats in the Mirror Conference Room of the Staszic Palace in Warsaw occupied, and additional people sitting on the stairs and on the floor, and standing. The Conference was run in Polish and English, with simultaneous translation. It commenced with an introductory talk by Prof. Michal Kleiber, President of the Polish Academy of Sciences. The introductory session comprised two presentations by invited foreign guests Prof. Hans Joachim Schellnhuber (Potsdam Institute for Climate Impact Research - PIK, Potsdam, Germany) and Mr Tom Sheldon (Science Media Centre, UK), who also spoke at the closing. Two discussion sessions were organized next. The first, led by Ms Ewa Podolska, a radio journalist (TokFM), dealt with communication of the results of scientific research on climate change to society. The second, led by Dr Andrzej Kassenberg, President of the Institute for Sustainable Development, dealt with the significance of the results of the IPCC AR5 for Poland. Among the panelists at the two sessions were decision makers, journalists, scientists, science writers, science brokers, and representatives of civil society.

Professor Michal Kleiber, President of the Polish Academy of Sciences, noted that people increasingly agree with the findings of IPCC reports, even if there are still skeptics. He also stated that we cannot avoid discussing the difficult problem of costs arising in the short term in the expectation of benefits in the long term. 


\section{INVITED LECTURES}

In his illuminating lecture, Professor Hans-Joachim (John) Schellnhuber, Director of the Potsdam Institute for Climate Impact Research (PIK) in Germany, a physicist by training, referred to physical laws and measurable (even if little known) numbers. He reviewed temperature variability over recent decades, stating that it has been beyond the long-term normal. He presented a suite of global maps of $\mathrm{CO}_{2}$ emissions over the last 250 years. Until the mid- $19^{\text {th }}$ century only Great Britain emitted meaningful amounts of $\mathrm{CO}_{2}$, but from the second half of the $19^{\text {th }}$ century onwards, considerable, and growing, emissions were emitted from Europe and North America. Meaningful emissions of $\mathrm{CO}_{2}$ in Asia as well as a global acceleration of emissions began after Word War II. For 200 years now we have seen an absolute upward trend for $\mathrm{CO}_{2}$ emissions.

Now, within the framework of the ARGO Project, we are measuring what is occurring in the deep ocean. Each of over 3000 buoys dives each day to the depth of 2000 meters to make a measurement. It is estimated that oceans have warmed by $0.09^{\circ} \mathrm{C}$ since 1950 . Considering the great thermal capacity of water, this warming (of $24 \times 10^{22} \mathrm{~J}$ ) could be translated into $36^{\circ} \mathrm{C}$ warming of the atmosphere. The greenhouse effect now corresponds to an energy flux comparable with the explosion of four of the atomic bombs that destroyed Hiroshima, each second. Part of this energy melts ice, while most of it warms the oceans, and the rest increases air temperature.

Professor Schellnhuber referred explicitly to an article published in SCIENCE, co-authored by Professor Z.W. Kundzewicz, while its principal message was that "stationarity is dead". Indeed, the changes are rapid. In the business-as-usual mode, by 2100 , the $\mathrm{CO}_{2}$ emission may have trebled, we will exploit all fossil fuels, and the temperature will have risen, on average, by $8^{\circ} \mathrm{C}$ (oceans less, continents more, possibly by $+12^{\circ} \mathrm{C}$ ). Alternatively, the assumption can be made that emissions peak in 2020, and then decrease, to reach negative emissions, through an energy revolution and the planting of trees to sequester carbon dioxide. What we are doing now will influence the fate of the world for 1000 years or more. There is so much carbon in the atmosphere that the next Ice Age may not occur.

Recently the Potsdam Institute for Climate Impact Research (PIK) prepared a report for the World Bank that was disseminated, via social media, to a billion readers. Professor Schellnhuber noted that this was the greatest success in the domain of the popularization of this category of science. The frequency of occurrence of deadly heat waves and destructive floods was analyzed, and projected changes for the future (important for insurers) were examined. An extreme event occurring once in a million years (a five-sigma departure from the mean) now could happen, on average, every year at a 4-degree warming. There would be no agriculture in the Tropics and subtropics. Tropical forests would disappear, with widespread impacts. There are interconnections between currents and streams of the air and our weather. The global system is complex. A large heat wave in Moscow may be tele-connected with a flood in Pakistan.

A rigorous analysis of temperature changes and associated costs had been carried out. To reduce warming by $1-2^{\circ} \mathrm{C}$, we would have to bear expenditures of $1-2 \%$ of 
GNP. If we delay the launching of the strategy by 15 years the global costs would grow five-fold. The numbers are largely country-specific, e.g. France depends on nuclear energy. We have to move forward, globally, to save the planet.

The next lecturer was Mr Tom Sheldon (Science Media Centre, UK), working in an institution located at the interface of science and the media. It translates science for use by the media, striving to ensure that science is reported with improved quality and accuracy. Efforts are made to base communications on scientific proofs. News outlets have expert science journalists who are specialists in their topic areas, but such specialized journalists often have to struggle to persuade their editors to publish articles that are technically competent and scientifically correct. Scientific debate should take place in the media, because the media shape people's opinions. A common interpretation of „Climategate”, i.e. the leaking of private mails between scientists in 2009 was as follows: conclusions about the warming have an unsound scientific basis. In order to rectify this misconception, the Science Media Centre organized a press briefing on climate change, attended by correspondents from the major media. Over 20 minutes, the scientists had talked, in a simple way, about facts indicating global warming. The role of a scientist is to be an honest broker. Scientists should inform the debate rather than seek to win it. They should repay the public with information. They should be politically neutral. Indeed, neutrality is key. The polls show that approximately $86 \%$ of British society thinks that science makes the world better. Confidence in scientists reaches $83 \%$ - a very high value. Only family doctors as a professional group are enjoying a higher confidence index, while journalists and politicians come much lower (at 18\% and 12\%, respectively). However scientists are perceived as poor communicators of results. Only $5 \%$ of society feels that scientists have adequate PR abilities. A call should be issued: Scientists! Speak out! If you do not, somebody else will! Mr Sheldon said that it was easy to believe in a conspiracy theory if the opponent was a dark character from far away. But sitting together with the opponent left it harder to believe that that person was actually an enemy. Summarizing, the speaker noted that every threat could be perceived as an opportunity. Climate change is the biggest challenge of our times and a longterm game had to be played, albeit with working together as a key factor if success is to be achieved.

\section{PANEL SESSION - COMMUNICATION OF THE RESULTS OF SCIENTIFIC RESEARCH ON CLIMATE CHANGE}

Next, a debate devoted to the communication of the results of scientific research on climate change to society was organized in the form of a panel session. This was moderated by a radio journalist, Ms Ewa Podolska (TOK FM), while the panelists were: Professor Zbigniew W. Kundzewicz, Mr Jacek Żakowski, Mr Marcin Popkiewicz, Mr Michał Koczalski, and Dr Przemyslaw Sadura. 
Ms Ewa Podolska stated that not long ago 7 out of 10 listeners calling the radio had signified that warming was a conspiracy. Now it is perhaps 4 out of 10 . However, the media are more interested in boosting the size of the audience than in informing it.

Professor Kundzewicz reviewed the interpretation of the AR5 findings in the Polish media and illustrated the range of sentiments present in the coverage. Occasionally, climate change had made the covers of illustrated opinion-forming magazines in Poland. It was natural that media reacted to current events, like an extreme heat wave or extreme cold wave (in the latter case, with global warming often being questioned and ridiculed). In general, global media balance inconvenient truths (using the rhetoric of Mr Al Gore) with convenient untruths. In contrast, Polish media often tended to prefer the dissemination of convenient untruths as a proxy for reality. Since the country sits on coal, the inconvenient truth is really very inconvenient. The number of skeptical articles is still large, but probably decreasing, as compared with the times of the earlier IPCC reports. Earlier cover stories of Polish magazines in the 2000s conveyed such exotic messages as: When will we be covered by ice?, New ice age. Scientists warn of large cooling, Global fooling, It will be colder. Is the global change only a business trick? These were the stories people wanted to read. Unfortunately, the title Global warming is a hoax is still present in the reactions of the Polish media to the $5^{\text {th }}$ IPCC Assessment Report, despite the overwhelming and indeed ubiquitous evidence of the warming. However, there are quite a number of objective articles in Polish media, reflecting the messages of the IPCC AR5.

Professor Kundzewicz also presented a slide with the results of his hindcasting of global temperature in relation to multiple climate drivers. The results clearly show that increasing $\mathrm{CO}_{2}$ concentration is the essential factor in interpreting the warming. Professor Leszek Marks (Warsaw University), known as an active climate skeptic, sought clarification as to which of the models from the IPCC report was used. He focused his attention on the weakness and poor accuracy of all the models used in the IPCC process. In reply, Professor Kundzewicz explained that the data-mining approach (evolutionary computation - genetic algorithm) used in his study lets the data speak for themselves, without the bias of assuming a particular model.

In his contribution, Mr Jacek Żakowski noted that, while the quality with which climate change was being communicated in the Polish media was improving, it remained the case that information sources were scattered. Large press titles from yesterday were nearly dead today, and what counted now was the blogosphere. Social media, such as Facebook and Twitter, act more effectively than the traditional media, and large media entities are under pressure from many smaller ones.

It was the view of Mr Żakowski, that public media culture had never even been born in Poland. There were state commercial media rather than truly public media. Press conferences referring to climate change did not attract as many journalists as in ripe democracies abroad. Hence in Poland it was small media entities that needed to be focused on, since the large ones could not be counted on. Knowledge transfer in 
small media entities was regarded as more efficient, and modern media are seen to act much more effectively than traditional ones that have quite an aggressive attitude in Poland. It is possible to modify the $19^{\text {th }}$ century saying that he who rules the oceans rules the land. In order to be effective in big media outlets, one should first colonize the small ones. There are typically problems at the science-media interface, and Polish scientists are not innocent. An average American scientist being interviewed has a clear message to convey, while an interview with a Polish scientist can be a nightmare. Polish scientists often do not paint a broad picture, do not talk directly, add "but" frequently, and provide a long list of caveats.

The essential 15-second rule is very strong in Poland. One cannot count on more than 15 seconds of attention from an audience. The aim of talking about climate should not be to convince the convinced. One should rather reach out to those who are not convinced, and this is much more difficult. The global warming story has strong and serious opponents, like Professor Leszek Balcerowicz (the former Deputy Prime Minister), who has negated facts related to climate change many times. Our society is not adequately educated.

Mr Marcin Popkiewicz (nuclear physicist, science writer) reported on an examination of the arguments of Professor Jaworowski (the best-known Polish climate skeptic, who died in 2012), who was shown to have made huge manipulations in his assumptions. A major problem there was the lack of sources in which information might be checked. The media popularize science but are not exact. At the other extreme, there are scientific reports that are not read by laypersons. How to talk about climate? First of all, very broadly, at meetings of different interest groups. According to Mr Popkiewicz, IPCC reports are conservative (while reality has turned out to be worse than the IPCC assumptions). This sentiment in fact resonates with the statement of Professor Chris Field, IPCC WG2 Co-Chair (USA), who used to say: "If we err then we should be on the conservative side" (comment added by Z.W. Kundzewicz).

Mr Michał Koczalski (Head of Energy \& Environment Practice / CEC Government Relations) noted that there are many actors on the communication map who speak different languages but should learn to understand each other. Mr Koczalski gave an example from his professional practice of advising industrial clients. The $\mathrm{CO}_{2}$ emissions from the paper plant in Kwidzyn had decreased by $70 \%$ since 1990 . A smart manager treats the issues of adaptation to climate change as an indispensable element of investment policy. There is a prejudice that industry and business act detrimentally, but it is not a general truth. Confidence is key. Promotion of companies based on pro-ecological trends gives good results. For example, the publicity campaign of the BGŻ bank has been a success. Their "I love bicycles" initiative received over 200000 "likes" on Facebook.

Dr Przemysław Sadura (Institute of Sociology, University of Warsaw) stated that, traditionally, science had had the privilege of enlightening society. But now science could not meet the promise that the world of nature would be subordinated to humankind. More and more often we deal with science that does not manage risk, 
but is a source of risk. Many human inventions turn against humankind. Globalization generates growing interdependence in the world and independent experts cease to exist. The progress of science is so immense that without experts we cannot comprehend it, but we have to be aware that most knowledge to be shared is in possession of those who have an interest in sharing it. Everyone represents some interests, so it is not possible to assume today that we can find independent and autonomous experts. The notion of the "public sociologist", who should try to represent the public interest, was coined. The existence of such entities is important now. Science cannot behave like the Church before the Reformation. Dr Sadura warned the IPCC against selfsatisfaction. We can lead a rational debate in our shrinking group but at the same time society may vote for something quite different. It is unwise to ignore opponents. Dr Sadura ended with the opinion that our climate is too important an issue to be left to climatologists alone.

Professor Maciej Nowicki (former Environment Minister) informed the audience that society is scared that the costs of $\mathrm{CO}_{2}$ emission reduction would be high. However, these costs can be nil, or very low. Companies do not spend money on lowering $\mathrm{CO}_{2}$ emissions. They spend money on the modernisation of their plants, introducing new, better and more efficient technologies. We do not insulate our houses in order to reduce $\mathrm{CO}_{2}$ emissions. We do this in order to pay lower bills for heating the house.

Ms Ewa Sufin-Jacquemart (Green Zone Foundation) expressed her astonishment that there is no broad knowledge in Poland as to what the IPCC is, or the circumstances underpinning the organisation's establishment. If an IPCC report is published, it has the same value in Poland as any other report, even though this should not be the case.

Professor Kundzewicz made a statement as an expert heavily involved in many IPCC activities (in various capacities, including as a four-time coordinating lead author) since 1994. He assured the audience that the IPCC is the collective voice of thousands of experts worldwide. It assesses available scientific, technical, and socio-economic information and issues authoritative statements. Yet there are climate sceptics in Poland, who express their critical opinions on the IPCC loudly, to the extent that these opinions penetrate the media, who are interested in disseminating convenient untruths.

According to Dr Cezary Lejkowski (EIT, Wrocław Research Centre), in Poland, facts and myths about climate change are being intermixed. At the practical level, climate-friendly solutions denote financial benefits for companies introducing relevant solutions. There are tens of thousands of such companies, and Poland is a pioneer in the case of some of the climate-friendly solutions.

Ms Renata Juszkiewicz (Responsible Business Forum) noted that the language used in communicating climate-change issues is very important. Her question concerned the manner in which we might move from a negative narration to a positive one, and from general communication to the addressing of a concrete target audience.

Dr Krzysztof Kamieniecki (Institute for Sustainable Development) questioned whether there was a demand for scientific information in Polish society? Did Poles 
feel the need for scientific support of their activities? Information had to be conveyed by credible institutions, but what was a credible institution in this case? The media could not be considered a credible institution.

Mr Bartosz Kwiatkowski (lobbyist) confessed that he had struggled to read half of the IPCC Summary for Policy Makers (AR5 WG I), and could not understand anything. He posed the question: To whom is it addressed? Probably, climatologists would understand but wider society definitely would not.

\section{PANEL SESSION - THE SIGNIFICANCE OF THE RESULTS OF THE IPCC AR5 FOR POLAND}

In the second debate, dealing with the significance of the results of the IPCC AR5 for Poland, and convened by Dr Andrzej Kassenberg, the panelists taking part were: Prof. Halina Lorenc, Minister Beata Jaczewska, Ms Daria Kulczycka, and Ms Urszula Stefanowicz.

Professor Halina Lorenc (Institute of Meteorology and Water Management, IMGW) explained that the Fifth IPCC Report mainly confirmed the general findings of the Fourth, albeit with augmented detail. The authors of the recent Report claim that, with at least $95 \%$ probability, mankind is responsible for global warming. Radiative forcing, largely due to a $40 \%$ increase in the atmospheric $\mathrm{CO}_{2}$ concentration since 1950 causes the warming. The last 40 years in Warsaw have been the warmest in the entire 230-year record of meteorological observations.

Ms Beata Jaczewska (Deputy Environment Minister of the Republic of Poland) explained that the Polish Government was examining possibilities for reducing emissions, as well as the resulting costs and benefits. This work is still ongoing, but it was announced publicly that Poland's greatest reduction potential is in energy efficiency. The Ministry is in the last stage of work on a strategic plan of adaptation to climate change, as a reaction to the corresponding European strategy. It has analysed climate change in the perspective to 2050, and has calculated the costs for particular economic sectors, arriving at a figure of 54 billion PLN of damage. The costs of adaptation of infrastructure could amount to c. 80 billion PLN in the years to 2020, and to over 110 billion by 2030. The whole infrastructure of Poland will have to be prepared for changes in weather extremes. Activities serving environment protection are elements of development policy, as per the Polish constitution.

Ms Daria Kulczycka (Confederation of Private Employers, Lewiatan) stated that, while business can sometimes be a source of environmental problems, it can also be one of the solutions to those problems. Business does not read IPCC reports, but it does read on the market and on politics, and, accordingly adjusts its activities, striving for efficiency. One exception is the insurance sector, which watches climate-related information very carefully. Environment policy must be an element of a broader economic policy of the country, and business will certainly subscribe to it. However, 
business is afraid that climate-relevant actions of the EU will be one-sided. It is always so that a threat to some is an opportunity to others, but the risk here is that all of us may lose. Europe may lose as a region due to restrictive regulation. Companies would go to the USA to avoid climate-related legislation. European business supports a global solution for climate problems in such a way that the $\mathrm{CO}_{2}$ price affects all actors on the market. Poland has a high-emission economy, so that reserves are high. For instance, in the housing sector, we can better insulate houses using Polish materials and technologies, creating a large market and acting in the name of ecology, at the same time.

Ms Urszula Stefanowicz (Coordinator of the Polish NGO Climatic Coalition) expressed the opinion "We are all treated as involved in some interests". According to her, each voice related to climate is regarded as a voice in someone's interest. Confidence is limited, as also NGOs are sometimes treated as public enemies, even if they act to the public benefit. Society needs help to interpret climate problems. Civic small-scale energy production, based on renewable energy sources, needs institutional and organizational support. Legal regulations are also needed if pro-climate activity is to be broadened.

Dr Krzysztof Kamieniecki (Institute for Sustainable Development) stated that people do not read IPCC reports, and that their knowledge depends on how the media inform them regarding report findings. The message of NGOs has no chance of passing across. The government is not quite convinced as regards pro-environmental activities, the opposition is not quite convinced either, while local and regional authorities do not know what to do, and NGOs meet with a wall.

In the opinion of Dr Witold Lenart (University of Warsaw), atmospheric science is complex, and so can be boring for the media. The media should inform people on just how many specialists know for sure that global warming is ongoing, compared with the number who think otherwise. This might eliminate doubts. The observed rate of warming has been unprecedented.

As is typical in Polish debates on climate change, there was also a verbal clash between skeptic and mainstream experts. Professor Leszek Marks questioned several of the claims made by speakers, asserting that high rates of temperature increase (higher than now) had occurred over a short time interval in the remote past, as had a much higher partial pressure of $\mathrm{CO}_{2}$ in ocean water in which organisms with calcium shells were abundant. There was a rebuttal on the part of the original speakers, but the positions of the parties did not change.

Professor Krzysztof Błażejczyk (University of Warsaw) said that it was typical for journalists to contact scientists expert on climate when there was a tornado, or an acute lack or excess of precipitation. The media are thus mainly interested in global climate change in the circumstances of weather-related disasters, rather than because a new IPCC report has been launched. 


\section{CONCLUDING REMARKS}

In the concluding session, Professor Schellnhuber, Mr Sheldon, and Professor Kleiber took the floor and wrapped up the discussion. The Conference was found to be very useful, and quite unique in the Polish landscape of polarised stances. The deliberations gave a food for thought on a range of issues relating to media and science in the context of climate change.

\section{ACKNOWLEDGEMENTS}

The participation of W.J. Kundzewicz and his work on preparing this note have been sponsored by the JPI Project Climate AR5 in Europe, funded by the Norwegian Research Council for JPI contributions.

Witold J. Kundzewicz Kundzewicz Management

Andrzej Kassenberg Institute for Sustainable Development

Zbigniew W. Kundzewicz Institute of Agricultural and Forest Environment, PAS 